\title{
Polymorphism identification of Diacylglycerol Acyltransferase1 gene and its correlation with fat content of Saanen goat
}

\author{
L. M. Y. D. Darmoatmodjo ${ }^{1}$, Widodo ${ }^{1,2, *}$ and W. Asmara ${ }^{1,3}$ \\ ${ }^{1}$ Centre of Biotechnology Studies, Universitas Gadjah Mada, \\ Jl. Teknika Utara, Depok, Yogyakarta 55281 - Indonesia \\ ${ }^{2}$ Department of Animal Product Technology, Animal Science Faculty, Universitas Gadjah Mada, \\ Jl. Fauna No 3, Bulaksumur, Yogyakarta 55281 - Indonesia \\ ${ }^{3}$ Department of Microbiology, Veterinary Faculty, Universitas Gadjah Mada, \\ Jl. Fauna No 2, Bulaksumur, Yogyakarta 55281 - Indonesia \\ *Corresponding E-mail : widodohs@ugm.ac.id
}

Received February 04, 2018; Accepted May 15, 2018

\begin{abstract}
ABSTRAK
Marka gen bermanfaat untuk membantu proses seleksi ternak terhadap fenotipe tertentu yang bersifat komersial. Kambing Saanen memiliki keunggulan dalam sifat produksi susu yaitu kadar lemak susu. Gen diacylglycerol acyltransferasel (DGAT1) terlibat dalam proses akhir sintesis trigliserida dan memiliki keterkaitan dengan kadar lemak susu. Perubahan nukleotida tunggal atau insersi-delesi pada sekuen tertentu dari gen DGAT1 dapat dijadikan marka genetik untuk sifat kuantitatif kadar lemak susu. Penelitian ini bertujuan untuk mengkaji perbedaan variasi kadar lemak susu antar individu kambing Saanen, melakukan identifikasi polimorfisme gen DGAT1 pada ekson 14-16 dan mengkaji keterkaitan polimorfisme dengan kadar lemak susu kambing Saanen. Tujuh puluh sampel darah dan susu dikoleksi, kemudian dilakukan isolasi DNA darah, amplifikasi gen DGAT1, sequencing, deteksi polimorfisme dengan metode Polymerase Chain Reaction-Single Strand Conformation Polymorphism (PCR-SSCP), dan uji kualitas susu pada 3 bulan laktasi menggunakan Lactoscan. Rata-rata produksi susu harian dari ketujuh puluh ekor sampel sebesar $2340 \pm 709 \mathrm{~mL} /$ hari, $1880 \pm 632 \mathrm{~mL} / \mathrm{hari}, 1432 \pm 536 \mathrm{~mL} / \mathrm{hari}$ dan ratarata kadar lemak susu sebesar $3.07 \pm 0.52 \%, 2.53 \pm 0.55 \%, 3.00 \pm 0.55 \%$, berturut-turut untuk bulan laktasi pertama, kedua dan ketiga. Ukuran amplikon ekson 14-16 gen DGAT1 sepanjang \pm 350 bp. Identifikasi polimorfisme dengan PCR-SSCP menghasilkan pola monomorfis. Variasi kadar lemak susu kambing Saanen tidak disebabkan oleh polimorfisme ekson 14-16 gen DGAT1.
\end{abstract}

Kata kunci: kambing Saanen, kadar lemak susu, DGAT1, polimorfisme, PCR-SSCP

\begin{abstract}
Gene markers are often usefull for selection process of cattle on commercial certain phenotypes. Saanen goat has predominance in milk production traits. Milk fat content is one of the commercial traits of milk production. Diacylglycerol Acyltransferase1 (DGAT1) gene was involved in the final process of triglyceride synthesis and associated with milk fat content. Single nucleotide subtitution or insertiondeletion in certain sequence of DGAT1 gene could be gene markers for milk fat content. The objective of this study was to identify differences variation in milk fat content among individual Saanen goats, to identify exon 14-16 polymorphism of DGAT1 gene and to examine its correlation between polymorphism and milk fat content on Saanen goats. The methodologies was collection blood and milk samples, DNA isolation from blood, amplification of DGAT1 genes, sequencing, detection of polymorphism of exon 14-16 DGAT1 gene with Polymerase Chain Reaction-Single Strand
\end{abstract}


Conformation Polymorphism (PCR-SSCP), and examination milk quality on three lactation months using Lactoscan. The average of daily milk production from 70 Saanen goat was $2340 \pm 709 \mathrm{~mL}$, $1880 \pm 632 \mathrm{~mL}, 1432 \pm 536 \mathrm{~mL}$ and average of milk fat content was $3.07 \pm 0.52 \%, 2.53 \pm 0.55 \%$, $3.00 \pm 0.55 \%$ for the first, second and third months of lactation, respectively. The amplicon size of exon 14-16 of DGAT1 gene was \pm 350 bp and showed monomorphic pattern from PCR-SSCP. Variation of milk fat content on Saanen goats not caused by polymorphism of exon 14-16 DGAT1 gene.

Keywords: Saanen goat, milk fat content, DGAT1, polymorphism, PCR-SSCP

\section{INTRODUCTION}

Benefits of goat milk had been widely felt by human being, so Indonesia needs to develop their dairy goat farm. Saanen goat has predominance in milk production. Development of Saanen goat breeding can not be separated from the selection process of livestock. Conventional selection based on ancestral performance takes a lot of time, so genetic markers underlying commercial phenotype trait as selection mechanism, or known as Marker-Assisted Selection (MAS) was used to abbreviate time and enhance the accurate of selection (An et al., 2013; Lehnert et al., 2015; Muhammed et al., 2015).

Milk fat content is one of the quantitative properties of commercial dairy traits. Milk fat contains $98 \%$ of triglycerides, synthesized from animal feed, de novo and from adipose storage in animal body (Osorio et al., 2016). The final synthesis of triglycerides is catalyzed by the diacylglycerol acyltransferasel (DGAT1) gene encoding the DGAT1 enzyme. The DGAT1 enzyme is an integral membrane protein present in the endoplasmic reticulum and used diacylglycerol and fatty acyl CoA as substrates for triglyceride synthesis (Ozmen and Kul, 2014; Rosse et al., 2014; Martin et al., 2017). DGAT1 gene as candidate of genetic marker in livestock selection process could identify with polymorphism at DNA level using Polymerase Chain Reaction-Single Strand Conformation Polymorphism (PCR-SSCP) (An et al., 2012; Raut et al., 2012; Shi et al., 2012).

According to quantitative trait locus (QTL) mapping, the DGATl gene has a strong association with milk fat content. Previous studies, Juhlin et al. (2012), Raut et al. (2012), Shi et al. (2012), Asmarasari et al. (2015), and Lehnert et al. (2015) used dairy cow and buffalo as samples, they found DGAT1 gene polymorphism on bovine chromosome 14, particularly on exon 8 , which is substitution of amino acid alanine to lysine at position 232 (K232A) related to higher milk fat content.
Although the location of DGAT1 gene in cows and goats is similar chromosome, but polymorphisms on exon 8 of dairy cows did not found in goats. Angiolillo et al. (2007) and An et al. (2013) showed that DGAT1 gene polymorphisms in goats associated with milk fat content were found insertion $\mathrm{C}$ on intron 14 and single nucleotide polymorphism (SNP) on intron 16 , substitution from thymine (T) to cytosine (C). The objectives study were to identify variation of milk fat content among individual Saanen goat, to identify polymorphisms include exon and intron 14-16 DGAT1 genes and its correlation with Saanen goat milk fat.

\section{MATERIALS AND METHODS}

\section{Animal Resource and DNA Isolation}

Sampling blood and milk was carried out in dairy goat farm in Balai Besar Pengembangan Ternak Unggul dan Hijauan Pakan Ternak (BBPTUHPT) Baturraden, Purwokerto, Central Java and polymorphism identification were conducted at the Laboratory of Genetic Engineering, Center of Biotechnology Studies, Universitas Gadjah Mada. Criteria of samples in this research were Saanen goat which postpartum status in February 2017, 2nd and 3rd lactation period, and less than 4 years old. Three mililiter of blood per sample from 70 Saanen goats were taken from blood collection by medical and paramedical staff of BBPTUHPT Baturraden. Furthermore, DNA isolation from goat blood using saturated phenol buffer method (Sambrook et al., 1989).

\section{PCR Amplification and Target Gene Checking}

Amplification of exon 14-16 DGAT1 gene was performed by PCR (Polymerase Chain Reaction) method. PCR reaction with a total volume of $25 \mu \mathrm{L}$ according to the protocol of Thermo Scientific DreamTaq Green PCR Master Mix (2X), a mixture of a solution consist of $1 \mu \mathrm{L}$ genomic DNA, $12.5 \mu \mathrm{L}$ DreamTaq Green PCR Master Mix (2X), $7.5 \mu \mathrm{L}$ nuclease free water, 2 
$\mu \mathrm{L}$ reverse primer and $2 \mu \mathrm{L}$ forward primer. The primers and PCR programs used in DNA amplification are shown in Table 1 and Table 2. The amplification result was identified by sequencing to ensure the target genes. Afterwards, sequence was analyzed by BLAST tools.

\section{PCR-SSCP and Final Sequencing.}

In SSCP-analysis, $2.5 \mu \mathrm{L}$ of PCR product was mixed with $9 \mu \mathrm{L}$ formamide dye $(98 \%$ formamide, $0.05 \% \mathrm{NaOH} 2 \mathrm{M}$ and $0.05 \%$ xylenecyanole) in micro tube, heated for 10 minutes at $98^{\circ} \mathrm{C}$ then immediately snap chilled on ice for 5 minutes. Sample was added into well of polyacrylamide gel with PAGE's concentration of $10 \%$ in $1 \mathrm{x}$ TBE buffer. Electrophoresis of DNA was hold on 300 volts for 1.5 hours and $\pm 15^{\circ} \mathrm{C}$. Polyacrylamide gel was removed from the glass then continued visualization with silver staining. The last, sequencing was divided into three categories: the highest, moderate and the lowest milk fat of goat milk.

\section{Milk Quality Test and Statistic Analysis}

Milk samples (50 mL/ewe) were taken once per month for March, April and May, respectively, every milking time (morning at $5 \mathrm{pm}$ and afternoon at $4 \mathrm{am}$ ). Measurement of milk fat content was used Lactoscan Milk Analyzer serial 17021 (Milkotronik Ltd). Data of milk production and milk fat content were analyzed using descriptive statistic while the influence of lactation time on fat content with paired t-test and One-way ANOVA analysis using SPSS 24.

\section{RESULTS AND DISCUSSIONS}

\section{Milk Production and Milk Fat Content}

The average lactation milk production for the first 3 months (Figure 1) were $2340 \pm 709 \mathrm{~mL}$, $1880 \pm 632 \mathrm{~mL}, 1432 \pm 536 \mathrm{~mL}$, and significantly different among lactation months $(\mathrm{P}<0.05)$. Lactation months with the highest milk production were obtained in the first month of post-partum lactation and decreased gradually each month. Norris et al. (2011) in their research found milk production would decrease followed by lactation month and Soeparno (2015) reported milk production depend on cattle body size, lactation period and hormonal level. The average milk fat contents of morning milking from Saanen goats on March, April and May were $2.72 \pm$ $0.48 \%, 2.18 \pm 0.44 \%$, and $2.61 \pm 0.25 \%$ while at afternoon were $3.43 \pm 0.71 \%, 2.92 \pm 0.58 \%$, and $3.39 \pm 0.13 \%$. Factors of milking and lactation time affect the milk fat content could be seen in Table 3. The range percentage from the highest and the lowest milk fat content was significantly different $(\mathrm{P}<0.05)$. It means, there are different variation of milk fat content between individual Saanen goats. Ensminger and Howard (2006) studied milk production decreased after lactation

Table 1. Primer for DGAT1 Gene Amplification

\begin{tabular}{llc}
\hline \multicolumn{1}{c}{ Primer } & \multicolumn{1}{c}{ Sequence $\left(5^{\prime}-3^{\prime}\right)$} & Source \\
\hline Forward & AGGAACTCGGAGTCCATCAC & An et al. (2013) \\
Reverse & TGAAGGCCCAGAGGCGGAAC & \\
\hline
\end{tabular}

Table 2. PCR protocol in Used

\begin{tabular}{clccc}
\hline Gene & \multicolumn{1}{c}{ Step } & Temperature $\left({ }^{\circ} \mathrm{C}\right)$ & Duration & Cycle \\
\hline \multirow{6}{*}{ DGAT1 } & Pre-denaturation & 95 & 5 minutes & 1 \\
& Denaturation & 95 & 30 second & \\
& Annealing & 58 & 30 second & 35 \\
& Extention & 72 & 2 minutes & \\
& Final extention & 72 & 10 minutes & 1 \\
\hline
\end{tabular}




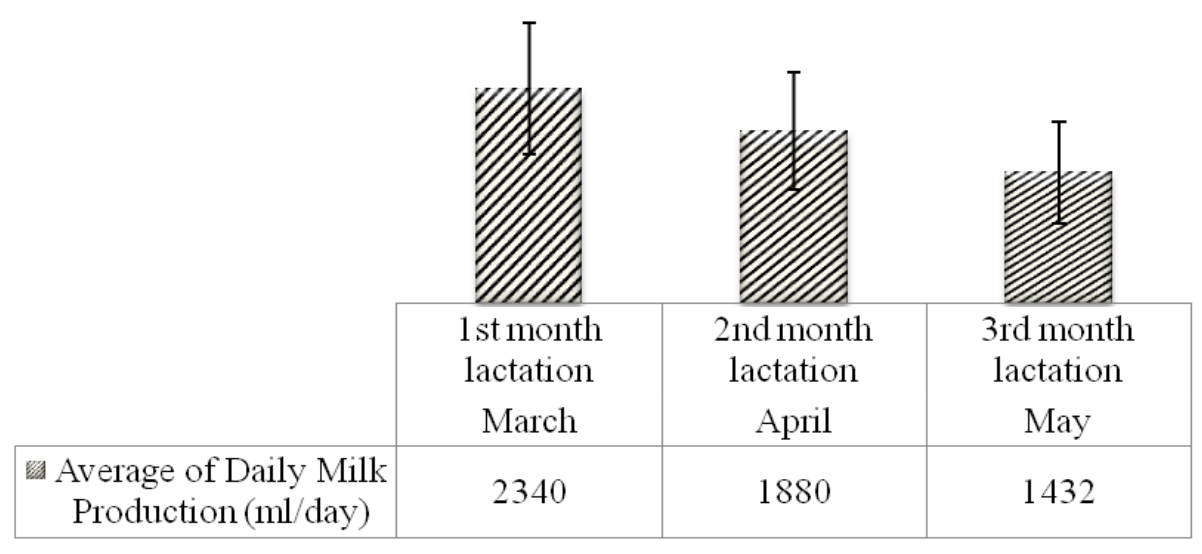

Figure 1. The Average Daily Milk Production of Saanen Goats is Based on the Lactation Month

Table 3. Average and Standard Deviation of Milk Fat Content (\%)

\begin{tabular}{lllll}
\hline \multirow{2}{*}{ Milking } & \multicolumn{3}{c}{ Lactation month } & \multirow{2}{*}{ Average } \\
\cline { 2 - 4 } & March & April & May & \\
\hline Morning & $2.72 \pm 0.48$ & $2.18 \pm 0.44$ & $2.61 \pm 0.25$ & $2.48 \pm 0.45^{\mathrm{a}}$ \\
Afternoon & $3.43 \pm 0.71$ & $2.92 \pm 0.58$ & $3.39 \pm 0.13$ & $3.24 \pm 0.58^{\mathrm{b}}$ \\
Milking average & $3.07 \pm 0.52^{\mathrm{A}}$ & $2.53 \pm 0.55^{\mathrm{B}}$ & $3.00 \pm 0.55^{\mathrm{A}}$ & \\
\hline
\end{tabular}

Different superscript letters on the same row and column show a noticeable difference $(\mathrm{P}<0.05)$

peak month and so did milk composition, but milk fat has another changes pattern because it will up gradually untill final lactation.

\section{Amplification of Exon 14 - 16 DGAT1 Gene}

The visualization of gene amplification in this research showed clear and bright single band, then size of amplicon was about \pm 350 base pair (bp) as presented in Figure 2. The sequencing results were analyzed using the Nucleotide BLAST (BLASTn) tool and showed the highest similarity, $97 \%$, with accession number LT221856.1 in Gene Bank. It refers to the DGAT1 gene sequence, so the PCR products were specific on target gene. Amplicon size was not far differently from An et al. (2012) investigate in the same exon target for Xinong Saanen and Guangzhou goat at China, approximately 328 bp.

\section{Analysis of Polymorphism Detection}

The polymorphism patterns of DGAT1 gene with PCR-SSCP in Saanen goat could be seen in Figure 3. Those were showed similar pattern of the entire sample or monomorphics pattern. According to An et al. (2013), the band pattern was obtained for Saanen goats in this study population indicated the $\mathrm{C}^{-} \mathrm{C}^{-}, \mathrm{C}$ genotype $\left(\mathrm{C}^{-}\right.$ means no $\mathrm{C}$ insertion). Hence, sequencing was done to ensure that all of sequences was monomorphic. Three samples were taken as the highest (T1), medium (M1) and the lowest (R1) percentage of goat milk fat content during 3 months lactation.

The sequencing results were aligned using MultAlin, and there was no difference nucleotide along sequence from samples. Neither subtitution of single nucleotide nor insertion-deletion was detected on those fragments. The alignment can be seen in Figure 4. The monomorphism was occured in the results of this study may indicate some reason. Firstly, it assumed there was polymorphism on different location of DGAT1 gene from this study. Secondly, mechanism of another genes which involved in the synthesis of triglyceride, so that a trait was not affected just only from the function of single gene. The process 


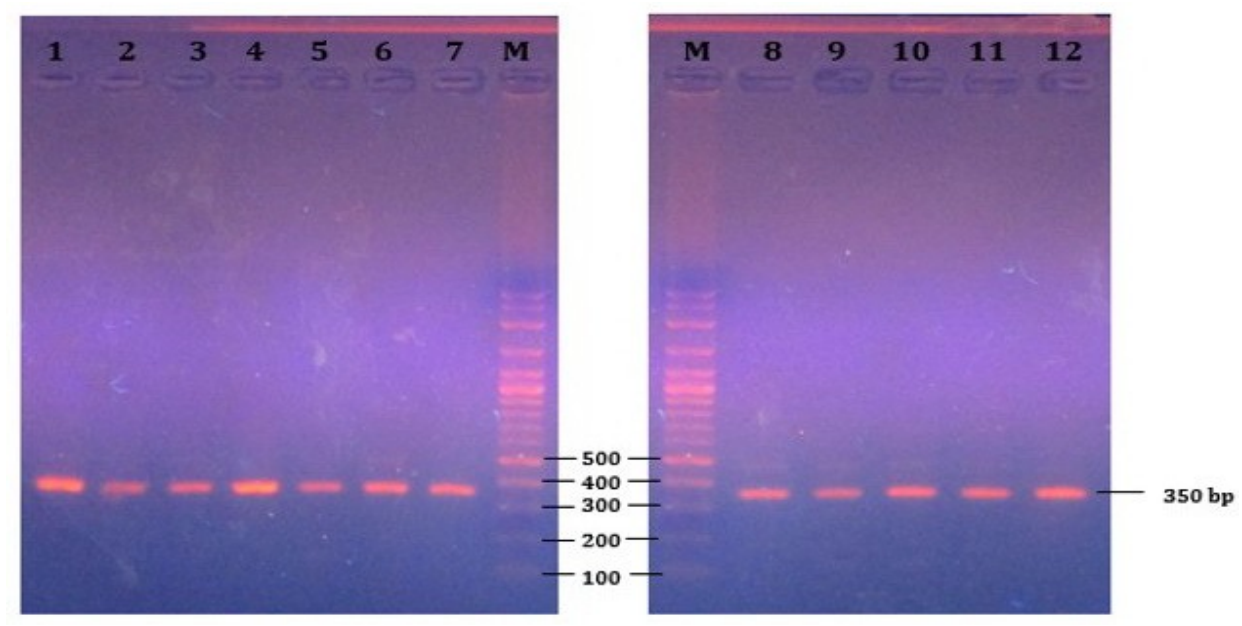

Figure 2. Visualization of the Result of DGAT1 Gene Amplification. Lane M: Marker 100bp (Geneaid), Lane 1-12: S0013, S0028, S0042, S0043, S0050, S0060, S0071, S0081, S0097, S0105, S0110, S0118 $(350 \mathrm{bp})$

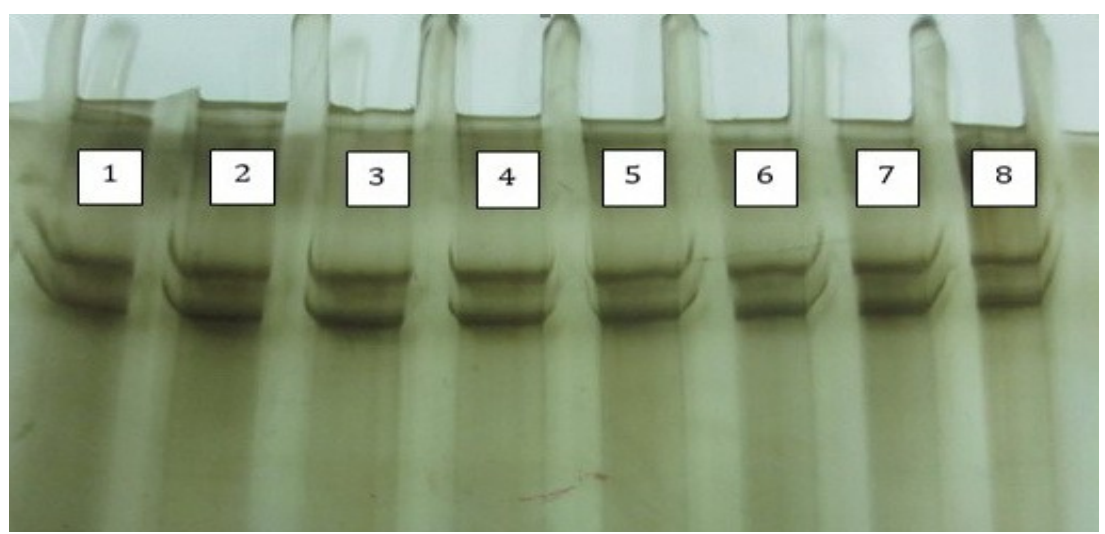

Figure 3. Monomorphic pattern of PCR-SSCP from one PAGE and other PAGE has the same pattern. Lane 1-8: sample with code S0013, S0028, S0042, S0043, S0050, S0060, S0071, S0078

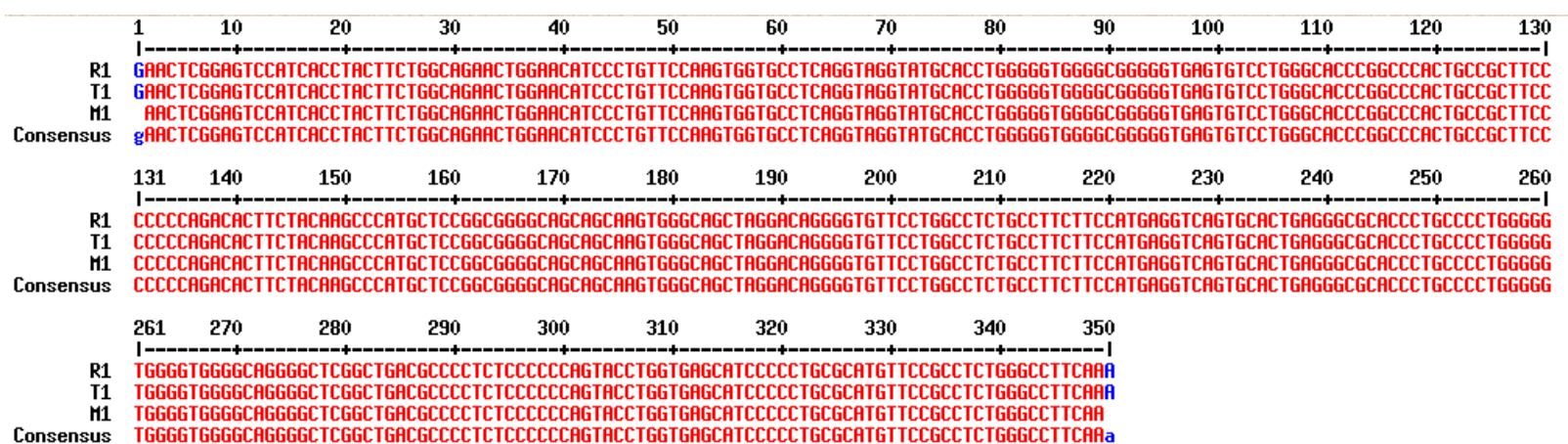

Figure 4. Results of alignment of samples with MultAlin. R1: the lowest milk fat content sample. M1: average milk fat content sample, T1: the highest milk fat content sample. 
of triglyceride synthesis involves genes from different gene families but work together in synthesis or it is known as polygenic. There were several genes that also play the role of coding enzymes in the process of triglyceride synthesis (TAG), include DGAT1. These genes include the GPAT gene (glycerol-3-phosphate acyltransferase), AGPAT (1-acyl-glycerol-3phosphate acyltransferase), $P P H-1$ (phosphatidate phosphohydrolase-1) or $P A P$ (phosphatidate phosphatase), MGAT (monoacylglycerol acyltransferase), and DGAT2 (diacylglycerol acyltransferase2) (Osorio et al., 2016; Zhu et al., 2016). Third, there is epigenetic speculation in DGAT1 gene regulation. Epigenetic was phenomenon which phenotypic changes caused by other mechanisms but genotype composition is similar. Elston et al. (2012), Jin et al. (2013), and Jiang et al. (2015) reported the effect of gene interactions with environmental factors, such as nutrition or chemical reaction could inhibit transcription factor then influence to expression on gene regulation.

\section{CONCLUSION}

The conclusions of the research results are there was significant differences in milk fat content among individual Saanen goats by lactation month and milking time, monomorphism pattern on exons 14 - 16 DGAT1 gene in Saanen goat and different variations of milk fat content does not caused by polymorphism of exons 14 16 DGAT1 gene. Next research, it possibly used more than one of specific gene marker of milk fat content traits and looking for its correlation.

\section{ACKNOWLEDGMENTS}

Thanks to BBPTUHPT Baturaden, Purwokerto-Central Java for providing Saanen goats and Mr. Toni Ruwaedi for helping laboratory works at Genetic Engineering Laboratorium, Center of Biotechnology Studies, Universitas Gadjah Mada.

\section{REFERENCES}

An, X. P., J. X. Hou, H. Zhao, C. M. Zhu, Q. M. Yan, Y. X. Song, J. G. Wang and B. Y. Cao. 2012. Mutations in caprine DGAT1 and STAT5 genes were associated with milk production traits. Engineering. 5:30-34

An, X. P., J.X. Hou, H. B. Zhao, L. Bai, J. Y.
Peng, C. M. Zhu, Q. M. Yan, Y. X. Song, J. G. Wang and B. Y. Cao. 2013. Polymorphism identification in goat DGAT1 and STAT5 genes and association with milk production traits. Czech J. Anim. Sci. 58 (7):321-327

Angiolillo, A., M. Amills, B. Urutia, A. Domenech, Y. Sastre, B. Badaoui, and J. Jordana. 2007. Identification of a single nucleotide polymorphism at intron 16 of the caprine Acyl-Coenzyme A: diacylglycerol acyltransferase 1 (DGAT1) gene. J. Dairy Res. 74(1):47-51

Asmarasari, S. A., C. Sumantri, I. W. Matius, and A. Anggraeni. 2015. Diacylglycerol Acyltransferase1 (DGAT1) gene polymorphism in New Zealand holstein friesian cattle under dairy breeding station and its correlation with milk quality. Proceedings. The $6^{\text {th }}$ International Seminar on Tropical Animal Production, Universitas Gadjah Mada, Yogyakarta, Indonesia. October 20-22, 2015. P. $418-422$

Elston, R., J. Satagopan and S. Sun. 2012. Genetic terminology. Methods Mol. Biol. 850: 1-9

Ensminger, M. E. and D. T. Howard. 2006. Dairy Cattle Science 4th Ed. The Interstate Printers and Publisher, Inc. Danville.

Jiang, Z., H. Dong, X. Zheng, S.L. Marjani, D. M. Donovan, J. Chen and X. (Cindy) Tian. 2015. mRNA levels of imprinted genes in bovine in vivo oocytes, embryos and cross species comparisons with humans, mice and pigs. Nature (Lond). 5:1-10

Jin, J., P. Iakova, M. Breaux, E. Sullivan, N. Jawanmardi, D. Chen, Y. Jiang. E.M. Medrano and N.A. Timchenko. 2013. Increased expression of enzymes of triglyceride synthesis is essential for the development of hepatic steatosis. Cell Reports. 33):831-843

Juhlin, J., W. F. Fikse, J. Pickova and A. Lundén. 2012. Association of DGATl genotype, fatty acid composition, and concentration of copper in milk with spontaneous oxidized flavor. J. Dairy Science 95(8):4610-4617

Lehnert, L., H. Ward, S. D. Berry, A. AnkersmitUdy1, A. Burrett, E. M. Beattie, N. L. Thomas, B. Harris, C. A. Ford, S. R. Browning, P. Rawson, G. A. Verkerk, Y. van der Does, L. F. Adams, S. R. Davis, T. W. Jordan, A. K. H. MacGibbon, R. J. Spelman and R. G. Snell. 2015. Phenotypic population screen identifies a new mutation 
in bovine DGAT1 responsible for unsaturated milk fat. Sci. Rep. 5:8484.

Martin, P., I. Palhiere, C. Maroteau, P. Bardou, K. Canale-Tabet, J. Sarry, F. Woloszyn, J. Bertrand-Michel, I. Racke, H. Besir, R. Rupp and G. Tosser-Klop. 2017. A genome scan for milk production traits in dairy goats reveals two new mutations in Dgat1 reducing milk fat content. Sci. Rep. 7: 1872.

Mohammed, S. A., S. A. Rahamtalla, S. S. Ahmed, A. Elhafiz, B.M. Dousa, K. M. Elamin and M.K.A. Ahmed. 2015. DGAT1 gene in dairy cattle. Global Journal of Animal Scientific Research 3(1):191-198

Norris, D., J. W. Ngambi, K. Benyi and C. A. Mbajiorgu. 2011. Milk Production of Three Exotic Dairy Goat Genotypes in Limpopo Province, South Africa. Asian J. Anim. Vet. Adv. 6(3):271-281.

Osorio, J. S., J. Lohakare and M. Bionaz. 2016. Biosynthesis of milk fat, protein, and lactose: roles of transcriptional and posttranscriptional regulation. Physiol. Genomics. 48(3):231-256

Ozmen, O and S. Kul. 2014. Polymorphism of goat DGAT1 gene anf their association with milk production traits. Indian J. Anim. Sci. 84(8):867-871

Raut, A. A., A. Kumar, S. N. Kala, V. Chhokar, N. Rana, V. Beniwal, S. Jaglan, S. K. Samuchiwal, J. K. Singh, and A. Mishra.
2012. Identification of novel single nucleotide polymorphisms in the DGAT1 gene of buffaloes by PCR-SSCP. Genet. Mol. Biol. 35(3):610-613

Rosse, I. C., R. S. Steinberg, R. S. Coimbra, M. G. C. D. Peixoto, R. S. Verneque, M. A. Machado, C. G. Fonseca, and M. R. S. Carvalho. 2014. Novel SNPs and INDEL polymorphisms in the 30UTR of DGAT1 gene: in silico analyses and a possible association. Mol. Biol. Rep. 41(7):45554563

Sambrook, J., E. F. Fritch and T. Maniatis. 1989. Molecular Cloning, a laboratory manual. Cold Spring Harbor Laboratory Press. New York.

Shi, D.S, J. Wang, Y. Yang, F.H Lu, X.P Li and Q.Y Liu. 2012. DGAT1, GH, GHR, PRL and PRLR Polymorphism in Water Buffalo (Bubalus bubalis). Reprod. Dom. Anim. 47(2): 328-334

Soeparno. 2015. Properti dan Teknologi Produk Susu. Gadjah Mada University Press. Yogyakarta.

Zhu, J. J., J. Luo, H. F. Xu, H. Wang and J. J. Loor. 2016. Short communication: Altered expression of specificity protein 1 impairs milk fat synthesis in goat mammary epithelial cells. J. Dairy Sci. 99(6):148934898 